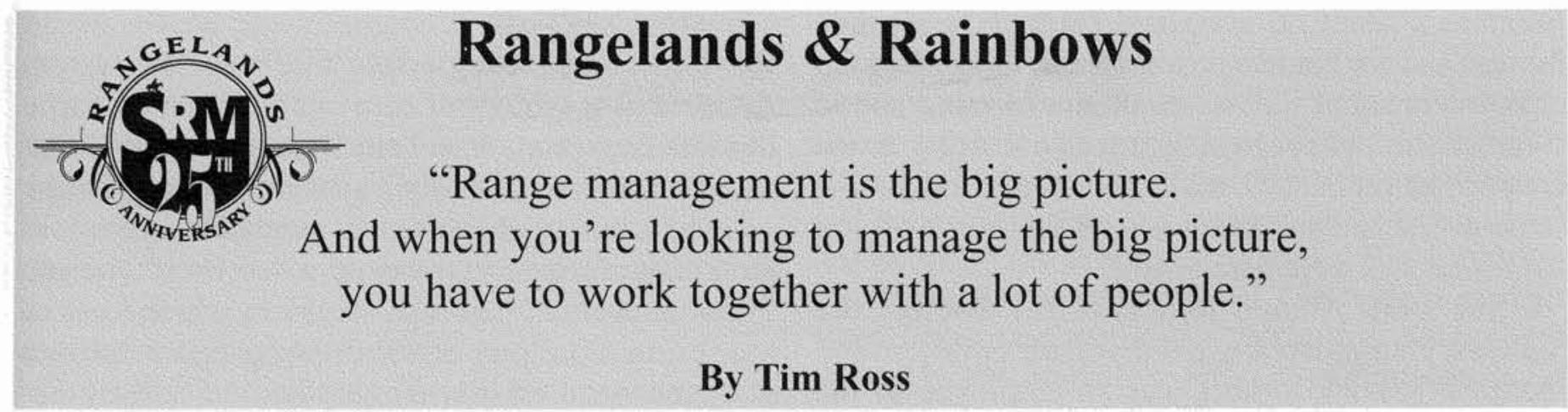

Editor's Note: Pacific Northwest SRM Section president Tim Ross gave the following address on April 29, 2003 at the summer workshop and tour hosted by the Pacific Northwest SRM Section and the Oregon Chapter of the American Fisheries Society in Prineville, Oregon.

Rangelands and rainbows - sounds like heaven to me. I'd like to talk to you today about the origins of the Society for Range Management (SRM), why the Trail Boss is our symbol, who we are today, and where we are going as a Society.

\section{Origins of the Society}

The profession of range management grew from concern over the abusive grazing of the open ranges that occurred during the latter half of the $19^{\text {th }}$ century, and after the turn of the century. Aggressive settlement of the West did not allow for conservative resource use. There was recognition that ecological principals had to be used to manage rangelands, particularly in the arid West, before 1920 .

The Society was founded in 1948 from an organization of 665 range scientists, educators and livestock operators. Livestock grazing was the principal use of rangelands at that time. Now we have broadened our scope. We are interested in, among other things, soil conservation, water quality and quantity, and a trend toward a more holistic view of agriculture. Range science pioneered this trend with its early ecosystem based approach to management.

Range management isn't just a Canada/US practice. When all the land in the world that presently sustains domestic grazing animals is taken into account, it comprises about $50 \%$ of the world's land area. Farmland accounts for $11 \%$, the other onethird is accounted for by wasteland - deserts, glaciers, high mountain peaks, and cities.
As a Society our published objectives are to:

- Properly take care of the basic rangeland resources of soil, plants and water;

- Develop an understanding of range ecosystems and the principles applicable to the management of range resources;

- Assist all who work with range resources to keep abreast of new findings and techniques in the art and science of range management;

- Improve the effectiveness of range management or obtain from range resources the products and values necessary for man's welfare;

- To create a public appreciation of the economic and social benefits to be obtained from the range environment;

- To promote the professional development of its members.

We publish a scientific journal, the Journal of Range Management and this companion magazine, Rangelands.

So what is range management? From a standard range management textbook:

"The art and science of optimizing the returns from rangelands in those combinations most desired by and suitable to society through the manipulation of range ecosystems."

Art and science - those 2 terms are meant to go together. The science we can all relate to, but the art implies that range management is an applied science that cannot be reduced to a technical or cookbook approach.

\section{The Trail Boss}

Speaking of art, does anyone know who Charlie Russell is? Charlie Russell (1864-1926) is best known as a western painter. But he was also known as a conservationist, for his disgust at seeing 
Montana's beautiful grasslands turned "grass-side down," and for his outspoken nature. When a group of boosters asked him to speak at a meeting and to comment on the progress that was occurring in the country, he replied, "I wish the country looked the same as the Indians knew it, and that none of you sons-a-bitches were here at all!"

In the 1949 Annual Report to the Society the Secretary suggested a need for an emblem and motto. Frederick Renner was an employee of the SCS who eventually became Chief of the Range Management division. When he received the typewritten copy of the 1950 Annual Meeting program for printing, he responded by attaching a photograph of Charlie Russell's drawing "the Trail Boss" and instructed the printer to reproduce it on the cover.

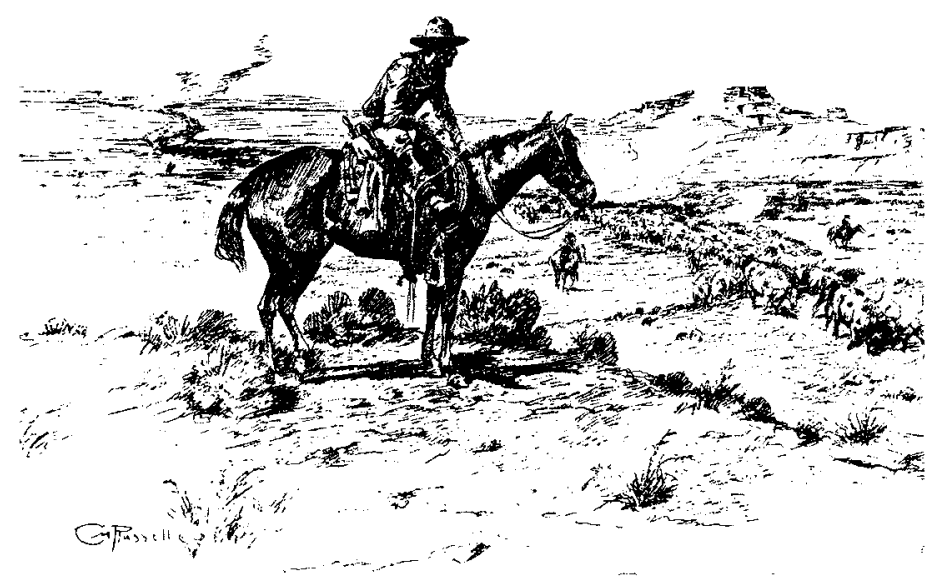

It was a hit at the 1950 meeting. The Trail Boss was registered in the U.S. office of patents as the official trademark of the Society for Range Management. Renner, who had known Russell personally as a childhood hero in Montana, also was an authority on Russell's life and work, and assembled the largest private collection of his works. Many of these were found in saloons in the northwest and central plains.

The Trail Boss symbolized the importance of strong leadership, the necessity of all hands working together, and a willingness to travel uncharted trails. He wasn't just a cowboy - that has connotations of carelessness. But then, for a generation or two raised on TV westerns what do you expect? I watched a couple of Gunsmoke episodes recently there was damn little ranching getting done, and no range management whatsoever!
The Trail Boss is in charge of the well-being of the cattle, horses, people and yes the range. Adopted as a symbol of care - as I believe Charlie Russell drew him. The Trail Boss is a symbol that we as members of SRM are stewards of rangelands.

There is talk of changing our symbol because people might perceive that we are a "cowboy" society. There is even a "new-age" version, which kind of spooks me. The part of the drawing that is left out of the new-age version shows a herd of cattle, horses and riders, and the beauty and the vastness of rangelands.

\section{Who Are We Today?}

Our membership in over 30 countries is about 3,600 . While we've had more members and there is some concern about numbers, there are both positives and negatives to a large membership.

As a society grows in size the interests of the members often tend to diverge. Beyond a certain size it may not be able to take a position on many questions because of the divergent interests and viewpoints of its members. On the other hand divergent viewpoints are likely to stimulate thought and discussion, and thereby lead to progress. They might stimulate the society to attempt to meet a greater variety of problems, and consequently enable it to grow in responsibility and influence. Moreover, an increased membership would permit more frequent issues of the Journal, provide the financial resources to allow us to sponsor certain worthwhile projects, and enlarge the influence of the Society in public affairs.

Those aren't my words, Frederick Renner wrote them in 1950.

We're a diverse bunch. Our membership ranges in age from about 18 to 80 . We come from many towns no-one has ever heard of and from large cities. Some of us look like cowboys, some of us like bankers, and some of us like skateboarders. But we're the same in at least one way - we're passionate about rangelands. We'd rather go out and just look at them: desert, shrub-steppe, grassland, forest or tundra, but we'll talk about them too; winter, spring, summer or fall; day or night; over coffee, or over beer. 
Sure, we have members who are grass managers or cow managers. But, we are also in no particular order: students, professors, cowboys, ranchers, administrators, researchers, consultants, salesmen, writers, and managers of all kinds of other things. We're soil scientists, animal scientists, plant physiologists, agrologists, biologists, climatologists, dendrologists, entomologists, and all the way up to zoologists. Hope I didn't leave anybody out.

But we're not bragging. That is because range is a kind of land, not a use of land. Range management is the big picture. And when you're looking to manage the big picture, you have to work together with a lot of people. You need a wide variety of people not just for their expertise, but also for their energy, their diversity of opinion, outlook and experience, and their humour.

Our broad membership base provides real strength. By creating internal forums representing a wide variety of interests, backgrounds, and objectives we have established an organization dedicated to not just grass, or livestock, or wildlife, or fisheries, but to a composite. But we need to join with other professional natural resource organizations. If we don't others who are less knowledgeable about rangelands will.

Again, not my words - a fellow named Joe Pechanec wrote them in 1967 . At least we're consistent.

While our broad membership does add a lot of value to our Society, occasionally we find ourselves on the opposite side of issues. It reminds me of a story that is told in the Chilcotin country of British Columbia. Quite a number of years ago the Forestry Department, which controls grazing on Crown lands, had apparently determined to build a new drift fence to control cattle on range near Riske Creek. The District Forester and other government men had addressed the Riske Creek Stockbreeder's Association and had produced many studies and statistics supporting their position. The audience was unmoved. The rancher's position was that the drift fence was a waste of taxpayer's money, that it was built of the wrong materials in the wrong place for the wrong reasons and that finally, and above all, the last thing they needed was help from the damned government. The government insisted. Discussions were heated. The rancher's were left with only one option to prevent the construction of the drift fence. They disbanded the Riske Creek Stockbreeder's Association.

\section{Where Are We Going?}

Speaking of consistent, where are we going? There is movement in our Society to keep evolving. In fact there is a program called "Journey to Change." There has been talk among some of changing our name, our symbol, and the names of our publications. At the International SRM meeting in Casper, Wyoming, back in February, a student from Texas said of SRM, "We're too cowboy for the environmentalists, and too environmentalist for the cowboys."

They say that in politics perception is reality, but who said anything about politics? Most of us with our science-based training were not thinking about going to meetings when we aspired to be a fisheries biologist or range conservationist or any other job. We wanted to be outside doing what we loved.

I believe the land use ethic espoused by SRM should not change, but I think we could improve our delivery. The Society has never been the "go-to" society when the media needs a quote or just clarification on an issue. The call often goes to an environmental or conservation organization that understands mass communication better than SRM does.

We at SRM are working on changing parts of our image so we can get our consistent message out recognizing that a program of sustainable multiple use, ecosystem management, holistic management, or call it what you will, can occur on any piece of rangeland.

To quote Mike Pitt and Art Bailey, range science professors in British Columbia and Alberta, "In preparing for the future we must remember that firstly, we serve the rangeland resource, secondly, the public that relies upon our expertise, and lastly, our own personal interests." The key is the resource, rather than any one user. The diversity of users will only increase.

I ask you, if you were in charge of the Prineville Land, Air, Water, Cattle, Trout, Elk, Timber and Recreation Company would you have your divisions squabbling with each other?

In 1963, one of our charter members, Bill Anderson, said, "The whole nation is going to learn the term multiple-use management. It will be put into effect in one manner or another." Part of how that happens is by shared meetings like this between the Pacific Northwest section of SRM, the Oregon Chapter of the American Fisheries Society, and all welcome guests. 